\title{
World Wide Uncharted Trajectory Outbreak Initiator: Coronavirus [COVID-19] Pathogenesis
}

\author{
Gajula Chinna Devi \\ Department of Pharmaceutics, University College of Pharmaceutical Sciences, Palamuru University, Mahabub Nagar, Telangana, \\ INDIA.
}

\begin{abstract}
The Coronavirus (CoV) belongs to family of Coronaviridae, suborder Coronavirinae and Nidovirales order. CoV causes diseases in human with a just cold, cough and high fever symptoms simultaneously develops in to severe respiratory syndrome and ceases fatal. The source of virus is believed to be "Wet Market" in Wuhan, China. The source of the latest pandemic has not yet been identified exactly but the original host is expected to be bats and mammals, which are host of wide range of Zoonotic viruses. The current trajectory state defines the virus is climbing rest of the world. The article is a descriptive study of CoV types, origin, transmission of virus from bats, mammals and inanimate surfaces to the host cells, life cycle of coronavirus where the Spike protein (S1 and S2) domains fusing with the receptors present on the host cell and other mechanisms. Steps of translation and exocytosis represented diagrammatically to control and mitigate the fatality. Worldwide therapy of the patients, a glance report on drug developments, stage of clinical trials and vaccine research is reported.
\end{abstract}

Key words: WHO, Zoonosis, RNA, Receptor, Vaccine.

\section{INTRODUCTION}

Wuhan, China has become a centre of epidemiology in the spread of COVID19 which is encountering a life and death question. We are facing a tough challenge like, SARS (Severe Acute Respiratory Syndrome) which has occurred in the year 2002. In November 2012, first confirmed the case of $\mathrm{CoV}$ was by the researcher and Virologist Ron Fouchier from Erasmus Medical Center (EMC), Rotterdam, where the sample has been received from Egyptian virologist Dr. Ali Mohammed Zaki. The COVID-19 pandemic is affecting worldwide in multiple ways like loss of work, lack of proper medical care and deficiency in food supply. ${ }^{1-5}$

A strategic team has been setup by World Health Organization (WHO) which is a source for governing different government agencies like the Center for Disease Control and Prevention (CDC). The World Health Organization (WHO), COVID-19 incident management team is working with partners like United Nations Childrens Fund (UNICEF), United National Office for Coordination of Humanitarian Affairs (UNOCHA), International Organization for Migration (IOM), International Organization for Red Cross and Red Crescent Societies (IFRC). ${ }^{6}$

The major areas like Risk communications and community management, International Federation of Risk Control (IFRC), UNICEF and WHO has formed a dedicated tripartite group to scale up and implement activities globally. The WHO head quartered in Geneva with help of public health England, the Indo Pacific health security Centre, the Australian Government and the Chinese centre for Disease control and prevention have sent staff to WHO to work on COVID-19 in Geneva, Switzerland, Manila, Philippines and New Delhi, India. ${ }^{6}$

The major partner coordination mechanisms are the emergency medical team (EMT), the Global Health Centre (GHC) and the
Submission Date: 15-04-2020; Revision Date: 02-08-2020; Accepted Date: 18-12-2020

DOI: 10.5530/ijper.55.1.4 Correspondence: Dr. Gajula Chinna Devi Assistant Professor, University College of Pharmaceutical Sciences, Palamuru University, Mahabub Nagar, Telangana, INDIA.

Phone no: +919441110223 Email id: gchinnadevi@ gmail.com

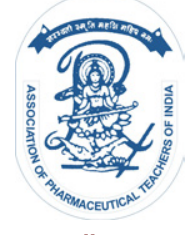

www.ijper.org 
Global Outbreak Alert and Response network (GOARN) which include technical agencies like NGO's including Medicines and Sans Frontiers (MSF). The health clusters across the country emphasize on case detection and focus on working closely on the deployment and implementation of measures in medical aid. Nearly 50 countries have requested support and GOARN are implementing strategies for direct country support and comprehensive technical briefings. ${ }^{6}$

Corona viruses are spherical, phenotypically and genotypically diverged and $\mathrm{CoV}$ are enveloped, singlestranded positive - sense RNA viruses belongs to the family Coronaviridae, suborder Coronavirinae and Nidovirales order. ${ }^{1-9}$ The origin of virus is expected to be "Wet Market" where both dead and live animals are been sold which includes mammals like pigs, mice, whales, snakes, cats, dogs, pangolins and birds like bats, cocks and ducks species. Transmission of viruses from Zoonotic origin to human is called as "spill over event". ${ }^{10}$ These CoVs causes neurological, hepatic and severe respiratory tract infections which may become fatal. Coronaviruses measures $65-125 \mathrm{~nm}$ in diameter and the genome size ranging from 26 to $32 \mathrm{kbs}$ in length. " "Coronavirus" can be viewed under two dimensional electron microscope and the name is derived from the Latin word corona means reminiscent of a crown or solar corona around the virions or halo and as per Greek kopwn (korone, "garland, wreath") (Figure 1a)..12,13

Health threats are long term with the CoVs due to the nature of easily altering the host tissue by tropism because of its capability of adapting the fresh and new environment through mutations. It is essential to control the spread for economic stability and global health by understanding the structure of CoV. Corona Viruses are classified into different genera namely as: Alphacoronavirus, Betacoronavirus, Gammacoronavirus and Deltacoronavirus. $\mathrm{CoV}$ known to infect humans are in the alpha and beta genera and identified in different species of birds and mammals as in Table 1.9,7,10,14

In $\mathrm{CoV}$ more prominent mutations can be observed which causes long term health issues like severe respiratory syndrome, gastro intestinal disturbances, nervous system disorders in human, Zoonotic species and finally causes death. ${ }^{21-23}$

The $\mathrm{CoV}$ is spherical and the RNA genome is helical, formed by nucleocapsid protein and surrounded by hemagglutinin-esterase viral membrane (HE), present in some beta corona viruses. Envelop associated with three proteins: crown like large prominences on virus surface which mediates the entry of virus into the host cells and change the immune responses of the host cell by Spike glycoprotein (S). The other two proteins which
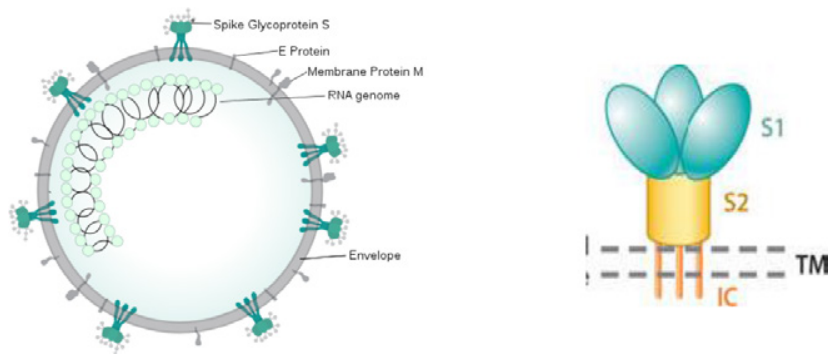

Figure 1: a. Corona virus structure..$^{34}$ b. Spike Glycoprotein (S). ${ }^{21}$

involves in the viral assemble are Envelop protein (E) and membrane protein (TM) ${ }^{21-30,8,19,31-33}$

The spike glycoprotein is clove shaped trimer when observed, composed of different parts like large Ectodomain part (S1 and S2), a Trans membrane anchor (TM) and intracellular tail (IC). Ectodomain consists of three headed S1 and stalk of trimer S2 subunits which are known as receptor-binding unit and membrane fusion sub unit respectively as in the Figure $1 b .^{21-30}$

\section{LIFE CYCLE OF COV: SPIKE PROTEIN BINDING WITH RECEPTOR ON HOST CELL}

Life cycle of coronavirus is contrived by binding of virus $\mathrm{S}$ protein with receptor host cell. The two important initial steps involved in the mechanism are receptor binding and membrane fusion. The S1 subunit binds with the receptor of host cell, for attachment and the S2 unit fuses to the host membrane and allowing the viral RNA genome to enter in to the host cell then, subsequent steps like translation and exocytosis steps takes place where the host immune system is affected. ${ }^{21,27-30}$ Virus may infect multiple host cells due to the loosely arranged glycoprotein spike receptor domain. There are two Receptor Binding Domains (RBD) present on spike namely small N-Terminal glycosylated domain (S1-NTD) and large C-Terminal domain (S1-CTD).

Viruses recognize and bind the receptors (Table 2 amino peptidases or angiotensin converting enzyme2 or exopeptidase or dipeptidyl peptidase 4) of the host cells as depending on the type of virus. Mechanism of coronavirus entry and Splitting the spike protein and establish penetration changes depends on the cellular proteases present in the host cells, cathepsins, human airway trypsin-like protease (HAT) and trans membrane protease serine2 (TMPRSS2). ${ }^{35-42}$

SARS-Cov-2 shows 3-D structure in the RBD region as the domain is composed of RNA polymerase, 3-chymotrypsin-like protease, papain-like protease, helicase, glycoprotein and accessory proteins which maintain Vander walls forces for the attachment and further fusion of viral envelop with cell membrane 


\begin{tabular}{|c|c|c|c|c|}
\hline Genus & Type of species & Host species & Common name & Habitat \\
\hline \multirow{9}{*}{$\begin{array}{l}\text { Alpha } \\
\text { Corona } \\
\text { virus }\end{array}$} & $\begin{array}{c}\text { Transmissible gastroenteritis } \\
\text { coronavirus (TGEV) }\end{array}$ & Sus scrofa & Wild swine or wild pig & America, south east Asia \\
\hline & Bat coronavirus $1 \mathrm{~A}$ & Miniopterus magnater & Small bent winged bat & $\begin{array}{l}\text { China, India, Indonesia, Laos, } \\
\text { Malasia, Mayanmar, New guinea } \\
\text { Thailand }\end{array}$ \\
\hline & Bat coronavirus 1B & Miniopterus pusillus & Small bent winged bat & $\begin{array}{l}\text { Bangladesh, India, Indonesia, } \\
\text { Malasia, Nepal }\end{array}$ \\
\hline & Bat coronavirus (HKU2) & Rhinolophus sinicus & Chinese horse shoe bat & China, India, Vietnam, Nepal \\
\hline & Bat coronavirus (HKU8) & Miniopterus pusillus & Small bent winged bat & $\begin{array}{l}\text { Bangladesh, India, Indonesia, } \\
\text { Malasia, Nepal }\end{array}$ \\
\hline & Human coronavirus NL 63 & Homo sapiens & Extent human species & World wide \\
\hline & $\begin{array}{c}\text { Human coronavirus 229E } \\
\text { (HCoV-229E) }\end{array}$ & Homo sapiens & Extent human species & World wide \\
\hline & $\begin{array}{l}\text { Porcine epidemic diarrhoea } \\
\text { coronavirus (PDEV) }\end{array}$ & Sus scrofa & Wild swine (pig) & America, South East Asia \\
\hline & Canine coronavirus (CCoV) & Canis lupus familiaris & Wolf species & North America, Eurasia \\
\hline \multirow{16}{*}{$\begin{array}{l}\text { Beta } \\
\text { corona } \\
\text { virus }\end{array}$} & Human corona virus HKU1 & Homo sapiens & Extent human species & World wide \\
\hline & Human SARS corona virus & Homo sapiens & Extent human species & World wide \\
\hline & Human coronavirus OC43 & Homo sapiens & Extent human species & World wide \\
\hline & Bat coronavirus HKU5 & Pipistrellus abramus & Japanese house bat & Japan \\
\hline & Bat coronavirus & Tylonycteris pachypus & Bamboo bat & South East Asia \\
\hline & Bat coronavirus HKU9 & $\begin{array}{l}\text { Leschenault's } \\
\text { rousettus }\end{array}$ & Fruit bat & $\begin{array}{l}\text { Palearrcitic, Australia, Indo Malayan } \\
\text { realm }\end{array}$ \\
\hline & Bat SARS coronavirus & Rhinolophus pearsoni & $\begin{array}{l}\text { Person's horse shoe } \\
\text { bat }\end{array}$ & $\begin{array}{l}\text { China, India, Laos, Mayanmar, Nepal, } \\
\text { Thailand }\end{array}$ \\
\hline & Bovine coronavirus & Bos taurus & Cattle or cow & Domesticated ungulates \\
\hline & $\begin{array}{l}\text { Porcine hem agglutinating } \\
\text { encephalomyelitis virus (HEV) }\end{array}$ & Bos taurus & Cattle or cow & Domesticated ungulates \\
\hline & $\begin{array}{l}\text { Civet severe acute respiratory } \\
\text { syndrome coronavirus }\end{array}$ & Paguma larvata & Masked palm civet & Indian sub- continent \\
\hline & $\begin{array}{l}\text { Human coronavirus } 4408 \\
\text { (HCoV-4408) }\end{array}$ & Homo sapiens & Extent human species & World wide \\
\hline & $\begin{array}{c}\text { Middle eastern respiratory } \\
\text { syndrome coronavirus } \\
\text { (MERS-CoV) }\end{array}$ & Homo sapiens & Extent human species & World wide \\
\hline & Mouse hepatitis virus (MHV) & Mus musculus & House mouse & World wide \\
\hline & $\begin{array}{l}\text { Mouse hepatitis virus RA59/R13 } \\
\text { coronavirus }\end{array}$ & Mus musculus & House mouse & World wide \\
\hline & Sambar deer coronavirus & Cervus unicolor & Sambar large deer & South China, South East Asia \\
\hline & $\begin{array}{c}\text { Severe acute syndrome } \\
\text { (SARS- CoV) }\end{array}$ & Homo sapiens & Extent human species & World wide \\
\hline \multirow{3}{*}{$\begin{array}{l}\text { Gama } \\
\text { corona } \\
\text { virus }\end{array}$} & Duck coronavirus & Anus & Duck & World wide \\
\hline & Infectious bronchitis virus (IBV) & Gallus gallus & Game cock & South East Asia \\
\hline & Turkey virus & Meleagris gallopavo & Turkey bird & South America \\
\hline \multirow{9}{*}{$\begin{array}{l}\text { Delta } \\
\text { corona } \\
\text { virus }\end{array}$} & Bul bul coronavirus HKU11 & Pycnonotus jocosus & Red whisked bulbul & Topical Asia \\
\hline & Porcine delta coronavirus (PdCV) & & Birds and chicks & United States \\
\hline & Magpie robin coronavirus HKU18 & Copsychus saularis & $\begin{array}{l}\text { Robin bird, world fly } \\
\text { catcher }\end{array}$ & World wide \\
\hline & Night heron coronavirus HKU19 & Nycticorax nycticorax & $\begin{array}{l}\text { Black crowned or black } \\
\text { capped night heron }\end{array}$ & Worldwide except coldest Australia \\
\hline & Munia corona virus HKU 13 & Lonchura striata & $\begin{array}{l}\text { White rumped munia, } \\
\text { mystery bird }\end{array}$ & South east Asia, China \\
\hline & Sparrow coronavirus HKU17 & Passer montanus & Eurasian tree sparrow & Asia \\
\hline & Thrush coronavirus HKU12 & Turdus hortulorum & Grey backed thrush & China, Russia \\
\hline & White eye coronavirus HKU16 & Zosterops species & White eye bird & $\begin{array}{l}\text { South east Asia, Australia, Africa, } \\
\text { Indonesia }\end{array}$ \\
\hline & Wigeon coronavirus HKU20 & Anas penelope & Eurasian wigeon & Eurasia \\
\hline
\end{tabular}


Table 2: Types of the coronavirus binding with type of Receptor on the host. ${ }^{47,51-61}$

\begin{tabular}{|c|c|}
\hline Virus & Receptor \\
\hline $\begin{array}{c}\text { Transmissible gastroenteritis } \\
\text { coronavirus (TGEV) }\end{array}$ & Sugar molecule \\
\hline Human corona virus & Amino peptidase \\
\hline $\begin{array}{c}\text { Porcine epidemic diarrhoea } \\
\text { coronavirus (PEDV) }\end{array}$ & Sugar molecule \\
\hline Canine coronavirus (CCoV) & Amino peptidase \\
\hline $\begin{array}{c}\text { Feline infectious peritonitis virus } \\
\text { (FIPV) }\end{array}$ & Amino peptidase \\
\hline Human coronavirus OC43 & Sugar molecule \\
\hline $\begin{array}{c}\text { Middle east respiratory } \\
\text { syndrome coronavirus } \\
\text { (MERS-CoV) }\end{array}$ & $\begin{array}{c}\text { Serine peptidase and } \\
\text { dipeptidyl peptidase 4 }\end{array}$ \\
\hline $\begin{array}{c}\text { Severe respiratory syndrome } \\
\text { respiratory syndrome } \\
\text { (SARS-CoV) }\end{array}$ & $\begin{array}{c}\text { Angiotensin converting } \\
\text { enzyme 2 (ACE 2) }\end{array}$ \\
\hline $\begin{array}{c}\text { Mouse hepatitis coronavirus } \\
\text { (MHV) }\end{array}$ & $\begin{array}{c}\text { Murine carcino embryonic } \\
\text { antigen related cell adhesion } \\
\text { molecule }\end{array}$ \\
\hline Infectious bronchitis virus (IBV) & Sugar molecule \\
\hline
\end{tabular}

takes place through endosomal pathway. Further the virus releases RNA (Ribonucleic acid) in to the host cell. Genome RNA is translated into viral replicase polyproteins pp1a and 1ab, which are then cleaved into small products by viral proteinases. By discontinuous transcription a series of sub genomic mRNAs are formed from polymerase. These sub genomic mRNAs then translated into pertinent viral proteins. Further these viral proteins and genome RNA assembled in the endoplasmic reticulum. These proteins move along the secretary pathway into the ERGIC membrane (intermediate compartment of endoplasmic reticulum and Golgi). There, viral genomes encapsidated by $\mathrm{N}$ protein bud into membranes of the ERGIC containing viral structural proteins, forming mature virions. Finally the virions released by exocytosis in to the cell by transportation through the vesicles. Mechanism of binding $\mathrm{CoV}$ spike protein with receptor on the host cell (Figure 2) ${ }^{21}$ and further steps of life cycle is as in the Figure $3{ }^{35,43-50}$

\section{TRANSMISSION}

The origin of $\mathrm{CoV}$ is mainly from bats and expected to transmit to human. The incognito method of this transmission from birds or animals to human is known as "spillover" method. Transmission is a particular phenomenon which happens when the droplets of infected person while coughing and sneezing containing the $\mathrm{CoV}$ could pass to other person via inanimate surfaces. The transmission is through potential intermediate

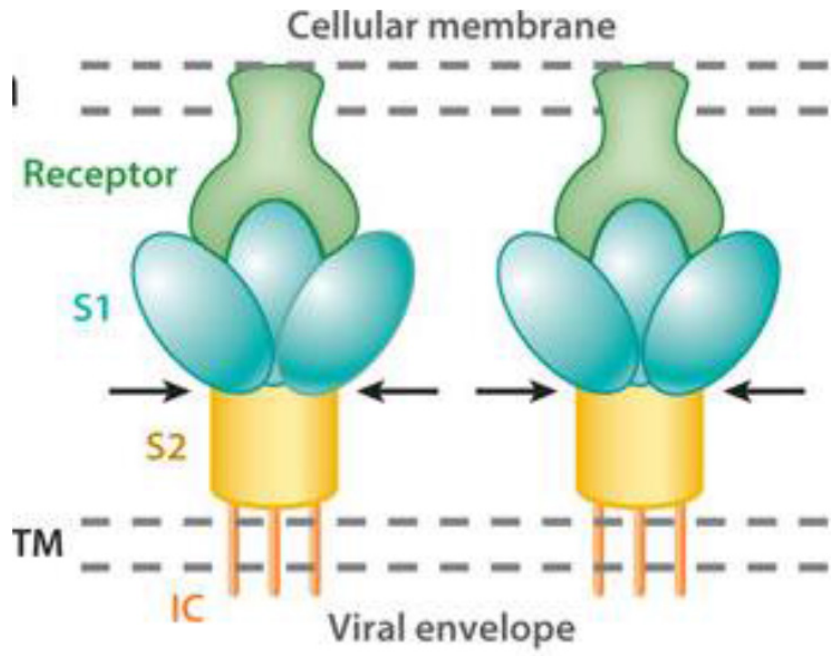

Figure 2: Mechanism of $\mathrm{S}$ protein binding with receptor on host cell. ${ }^{21}$

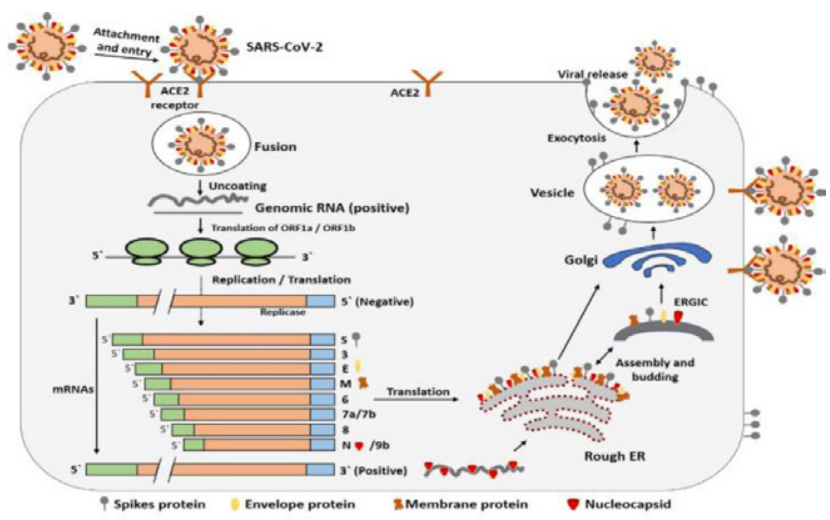

Figure 3: Life cycle of CoV- Binding, fusion, translation and exocytosis. ${ }^{35}$

hosts and persistence of virus on inanimate surfaces (Table 3) but there is no scientific literature available as the virus detection in environment. ${ }^{62-67} \mathrm{In}$ human $\mathrm{CoVs}$ cause lower and upper respiratory tract infections that can be mild, such as common cold is predominantly by Rhino viruses and others can be lethal such as SARS, MERS and COVID. Experts has to identify the potential interventions to mitigate transmission and host pathogen relationship to control or mitigate the $\mathrm{CoV}$ uncharted spreading. Figure 4 represents hypothesized origin of coronavirus transmission to human depending on the how close to to the infected person. ${ }^{34,62,68}$

\section{Basic protective measures to be taken as per WHO ${ }^{78}$}

1. Washing hands with soap water or alcohol based solutions kill viruses that are on the hand after in contact with virus.

2. At the time of sneezing or coughing the human small droplets from their nose or mouth containing 


\section{Table 3: Type of inanimate surface and persistence of corona virus ${ }^{69-78}$}

\begin{tabular}{|c|c|c|}
\hline $\begin{array}{c}\text { Type of the inanimate } \\
\text { surface }\end{array}$ & $\begin{array}{c}\text { Temperature } \\
\text { range }\end{array}$ & $\begin{array}{c}\text { Persistence time } \\
\text { depending on type } \\
\text { of virus }\end{array}$ \\
\hline Aluminium & $21^{\circ} \mathrm{C}$ & 2 to $8 \mathrm{hr}$ \\
\hline Ceramic & $21^{\circ} \mathrm{C}$ & 5 days \\
\hline Disposable gowns & $\mathrm{RT}$ & $1 \mathrm{hr}-2$ days \\
\hline Glass & $21^{\circ} \mathrm{C}-\mathrm{RT}$ & $4-5$ days \\
\hline Metal & $\mathrm{RT}$ & 5 days \\
\hline Paper & $21^{\circ} \mathrm{C} \mathrm{to} \mathrm{RT}$ & $5 \mathrm{~min}-5$ days \\
\hline Plastic & $20^{\circ} \mathrm{C}-\mathrm{RT}$ & $8 \mathrm{hr}$ to 5 days \\
\hline PvC & $21^{\circ} \mathrm{C}$ & 5 days \\
\hline Steel & $4^{\circ} \mathrm{C}-40^{\circ} \mathrm{C}$ & $48 \mathrm{hr}$ \\
\hline Silicon rubber & $21^{\circ} \mathrm{C}$ & 5 days \\
\hline Surgical glove & $21^{\circ} \mathrm{C}$ & 5 days \\
\hline Teflon & $21^{\circ} \mathrm{C}$ & $8 \mathrm{hr}$ \\
\hline Wood & $21^{\circ} \mathrm{C}$ & 5 days \\
\hline
\end{tabular}

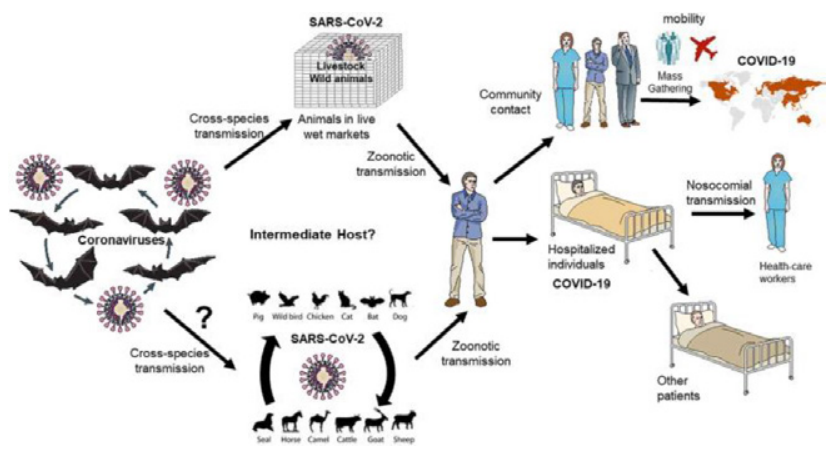

Figure 4: Transmission of coronavirus from originated source and inanimate surfaces to human. ${ }^{62}$

virus will spills out. So atleast 1 meter distance to be maintained from one person to other.

3. Avoid touching of nose, mouth and eyes because there is chance of virus transmission from inanimate surfaces through hands and then in to the special sensed organs.

4. Respiratory hygiene is practiced and try to use masks.

5. Incase of cough, cold, fever and difficulty in breathing consult local healthcare personnel.

6. Share the latest facts and avoid hyperbola.

7. Show solidarity with affected people.

8. Avoid spitting in public.

9. Pregnants and women after child birth has to be concious by disinfecting herself.

10. Counseling to be done to the patients and suspected patients to relieve from stress during crisis.

11. Maintaining healthy life style with proper sleep, diet, exercise and avoid travelling.
12. Avoid smoking and consuming alcohol which may increase fatality.

13. Children may be clingy, anxious or angry with the situation, spend more time with the kids and engage them with extracuricular and brain storming activities within the house.

\section{SYMPTOMS}

After transmission of the virus from the bird or animal species or through inanimate surfaces to the host by spill over method, the incubation period of virus is approximately 5.2 days to 14 days, the length of time before symptoms appear.

Common symptoms observed are sneezing, coughing, headache, diarrhoea, dyspnea, haemoptysis and lymphopenia. Acute cardiac injury, acute respiratory distress syndrome and incidence of ground-glass opacities are the causes of fatality. Gastrointestinal distress also experienced in the patients. Clinical features like pneumonia, acute cardiac injury and ground-glass syndrome can be diagnosed by CT scan and dyspnea with hypoxemia by chest radiography. Figure 5 is showing diagramatic representation of COVID-19 disorders showing in human..$^{79-87,6,14,17}$

\section{DIAGNOSIS}

India's first drive through COVID-19 is Dr. Dangs lab, one of the first private laboratories allowed to test for coronavirus. An ability to rapidly diagnose the virus is of invaluable help in curbing it's exponential spread in many countries. Bosch's rapid test is one of the world's fully automated molecular diagnostic tests that can be used directly by all medical institutions. The test is rapid and meets the quality standards of WHO. In the present challenging scenario COVID-19 tests plays major role

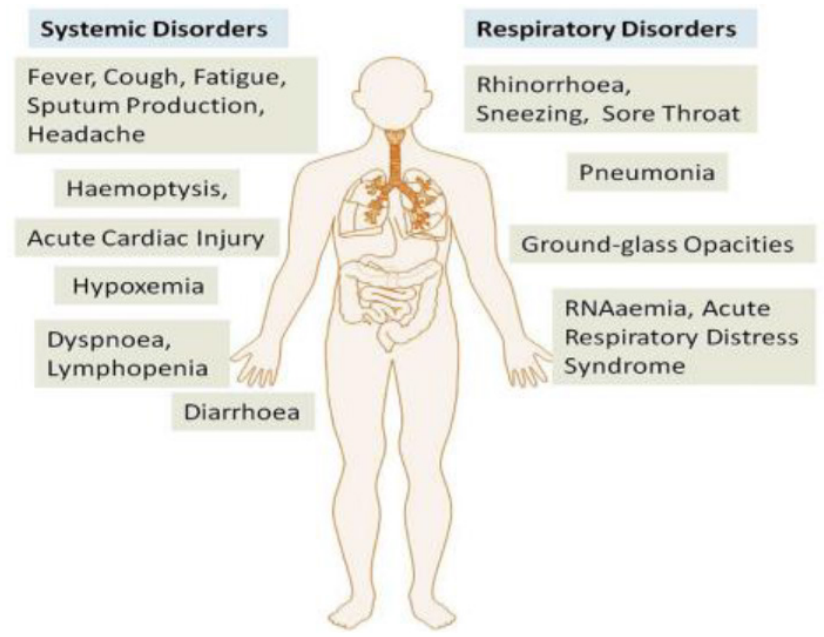

Figure 5: Disorders showing in Human upon CoV infection. ${ }^{79}$ 
in testing the pandemic and giving medication or to give precautionary suggestions to public. The most reliable and accessible testing methods are PCR (Polymerize chain reaction) or serologic tests. Some other disorders like ground-glass syndrome can be identified by CT scan and dyspnea with hypoxemia by chest radiography. 88,89

\section{DRUGS AND VACCINES DEVELOPMENT}

World Health Organization (WHO), United States Food and Drugs Administration (USFDA), European Medicines Agency (EMA), Chinese government, nearly 100 drug manufacturers and biotechnology firms were coordinating with researchers to develop antiviral drugs, vaccines and monoclonal antibody therapies. ${ }^{90-98,7-10}$

In March, Canadian Government announced CA $\$ 275$ million funds for development of "vaccine bank" and Coalition for Epidemic Preparedness Innovations (CEPI) released funds for this outbreak. World Health Organization implemented "SOLIDARITY Trail" in different countries for monitoring the COVID-19 affected and treated patients by therapy with antiviral drug. ${ }^{90,99}$

The "COVID View" is the analyzed report of COVID-19 by center for disease control and prevention where the organization monitor the weekly surveillance report and updates on every Friday regarding the outpatient visits, emergency department visits, hospitalized cases and deaths, as well as laboratory data. ${ }^{100}$

By the end of March 2020 Favipiravir, Remdesivir, Ritonavir and Hydroxy chloroquine (chloroquine) antiviral drugs were at final stage of clinical trials III and IV phase. Remdesivir drug has been advised to the physicians for patients who were hospitalized with pneumonia by United States Centers for Disease Control and Prevention (CDC) on $21^{\text {st }}$ March 2020. ${ }^{101,102,95,103}$

Novel molecules are emerging trends for drug development and vaccine preparation. The major and first objective of the drug discovery or development is "First-in-Human" (FIH) or "First Human Dose" (FID). For new entity to launch in the mar is more important for new chemical entity launch in the market it is very essential to satisfy the regulatory requirements and licensing authorities. ${ }^{104-106}$

The major COVID-19 outbreak has initiated for the development of vaccines as in Table 4. In solidarity trail, different combination of drugs used are LopinavirRitonavir, Lopinavir-Ritonavir combined with interferon-beta, Remdesivir or Hydroxychloroquine in separate trials and hospital sites internationally. ${ }^{75,90}$

Clinical studies has been carrying on Vasodilators, corticosteroids, immune therapies, lipoic acid, bevacizumab

\begin{tabular}{|c|c|c|}
\hline $\begin{array}{c}\text { Name of the drug/ } \\
\text { vaccine }\end{array}$ & $\begin{array}{l}\text { Clinical trials } \\
\text { phase and } \\
\text { category }\end{array}$ & $\begin{array}{l}\text { Manufacturer I } \\
\text { research country }\end{array}$ \\
\hline Covaxin & Inactivated vaccine & $\begin{array}{c}\text { Bharath Biotech } \\
\text { India Limited/Indian } \\
\text { Council of Medical } \\
\text { Research and } \\
\text { National Institute of } \\
\text { virology }\end{array}$ \\
\hline ChAdOx1-S & $\begin{array}{l}\text { Non replication } \\
\text { viral vector }\end{array}$ & $\begin{array}{l}\text { University of Oxford/ } \\
\text { Astra Zeneca }\end{array}$ \\
\hline $\begin{array}{c}\text { mRNA-1273 } \\
\text { (Moderna vaccine } \\
\text { candidate) }\end{array}$ & I & Unites States \\
\hline $\begin{array}{l}\text { Adjuvanted } \\
\text { recombinant } \\
\text { protein (RBD } \\
\text { Dimer) }\end{array}$ & Protein sub unit & $\begin{array}{l}\text { Anhui Zhifei } \\
\text { Longcom } \\
\text { Biopharmaceuticals/ } \\
\text { Institute of } \\
\text { Microbiology, } \\
\text { Chinese academy of } \\
\text { science }\end{array}$ \\
\hline $\begin{array}{l}\text { DNA Vaccine (GX- } \\
19)\end{array}$ & DNA & $\begin{array}{l}\text { Genexine } \\
\text { Consorteum }\end{array}$ \\
\hline $\begin{array}{l}\text { DNA Plasmid } \\
\text { Vaccine }\end{array}$ & DNA & $\begin{array}{c}\text { Cadila Health care } \\
\text { Limited }\end{array}$ \\
\hline $\begin{array}{l}\text { DNA Plasmid } \\
\text { Vaccine with } \\
\text { electroporation }\end{array}$ & DNA & $\begin{array}{c}\text { Inovio } \\
\text { Pharmaceuticals / } \\
\text { International Vaccine } \\
\text { Institute }\end{array}$ \\
\hline Ad26COVS1 & $\begin{array}{l}\text { Non Replicating } \\
\text { Viral vector }\end{array}$ & $\begin{array}{c}\text { Janssen } \\
\text { Pharmaceutical } \\
\text { companies }\end{array}$ \\
\hline $\begin{array}{l}\text { Ad5-nCoV } \\
\text { (Recombinant } \\
\text { adenovirus } \\
\text { vaccine) }\end{array}$ & RNA & China \\
\hline Favipiravir (Avian) & III & Shenzhen, China \\
\hline $\begin{array}{l}\text { ASC-09+Ritonavir } \\
\text { (ASC-09 oral } \\
\text { tablets }\end{array}$ & $\begin{array}{l}\text { III, HIV-1 protease } \\
\text { inhibitor }\end{array}$ & China \\
\hline $\begin{array}{l}\text { Tocilizumab } \\
\text { (Actemra) }\end{array}$ & $\begin{array}{l}\text { III, monoclonal } \\
\text { antibody with } \\
\text { activity against } \\
\text { the interleukin- } 6 \\
\text { receptor }\end{array}$ & $\begin{array}{l}\text { Across several } \\
\text { countries }\end{array}$ \\
\hline $\begin{array}{l}\text { Chloroquine } \\
\text { or Hydroxy } \\
\text { chloroquine }\end{array}$ & IV & China \\
\hline $\begin{array}{l}\text { BDB-1 (Beijing } \\
\text { defengrei } \\
\text { biotechnology) }\end{array}$ & $\begin{array}{l}\text { II, anti-C5a } \\
\text { monoclonal } \\
\text { antibody }\end{array}$ & $\begin{array}{c}\text { Staid son } \\
\text { pharmaceuticals, } \\
\text { Beijing }\end{array}$ \\
\hline Brilacidin & $\begin{array}{l}\text { II, polymer based } \\
\text { antibiotic }\end{array}$ & $\begin{array}{l}\text { University of } \\
\text { Pennsylvania }\end{array}$ \\
\hline $\begin{array}{c}\text { Kevzara } \\
\text { (Sarilumab) }\end{array}$ & $\begin{array}{c}\text { II, anti- } \\
\text { inflammatory }\end{array}$ & $\begin{array}{l}\text { Sanofi and } \\
\text { Regeneron }\end{array}$ \\
\hline $\begin{array}{l}\text { IFN- } \alpha \text { (human } \\
\text { interferon alpha) }\end{array}$ & $\begin{array}{l}\text { Immune therapy, } \\
\text { cytokine activity }\end{array}$ & \\
\hline Umifenovir & & $\begin{array}{l}\text { China traditional } \\
\text { medicine }\end{array}$ \\
\hline
\end{tabular}


and Recombinant angiotensin-converting enzyme2. ${ }^{107-110}$ As per the WHO data 26 vaccines are under clinical evaluation and 139 vaccines are under pre-clinical trials. ${ }^{111}$ Treatment by plasma therapy is also under clinical trials and waiting for the success rate to control COVID-19.

\section{CONCLUSION}

Reaching to a conclusion has to start with the root cause of the COVID-19, the pandemic with many cases cropped up in China and now whole World is being attacked and the reason for the spread is the "Wet Market" in Wuhan, China. Few medical teams have come up with many researches who are thoroughly struggling to put an end to the cause, spread and take further steps for prevention and cure. Many pharmaceutical companies, Biotechnology firms, Research centers and University researchers announced partnership and jointly developing mRNA based vaccines which are currently in pre-clinical studies. Treatment by plasma therapy is also under clinical trials and hope for the success to control COVID-19.

With a positive note we can conclude that, at the present scenario it's not only India but other nations are also tacking remedial measures to mitigate and face the challenge of COVID-19 sufferings. To the best of medical knowledge hope the next generation will have a formulation to overcome the pandemic uncharted death path of trajectory outbreak.

\section{ACKNOWLEDGEMENT}

I owe my heartfelt gratitude to my father Late Sri G. Nagesam for making me professional and work minded. I am deeply thankful to G. Prasanthi; Freelancer in Management Institutions, Bangalore, for her discussions regarding the work has become more illuminating. Finally I am thankful to all my family members for supporting me to complete the work in time. Last but not the least my deepest gratitude to all the Essential Service Providers during the typical and complicated situation of human survival in the COVID-19 uncharted death path of trajectory outbreak.

\section{CONFLICT OF INTEREST}

There are no conflicts of the interest to declare.

\section{ABBREVIATIONS}

COVID-19: Coronavirus Disease-19; CoV: Coronavirus; SARS: Severe Acute Respiratory Syndrome; MERS: Middle East Respiratory syndrome; EMC: Erasmus Medical Center; CDC: Center for Disease Control and
Prevention; RT: Room Temperature; HIV: Human Immunodeficiency Virus; WHO: World Health Organization;UNICEF:UnitedNations ChildrensFund; UNOCHA: United National Office for Coordination of Humanitarian Affairs; IOM: International Organization for Migration; IFRC: International Organization for Red Cross and Red Crescent Societies; EMT: Emergency Medical Team; GHC: Global Health Centre; GOARN: Global Outbreak Alert and Response network; MSF: Medicines and Sans Frontiers; RBD: Receptor Binding Domains; HAT: Human Airway Trypsin-like protease; TMPRSS2: trans membrane protease serine2; RNA: Ribonucleic acid; ERGIC: Intermediate Compartment of EndoplasmicReticulumand Golgi;HE:Hemagglutinin Esterase Viral Membrane; TGEV: Transmissible gastroenteritis coronavirus; PEDV: Porcine epidemic diarrhoea coronavirus; CCoV: Canine coronavirus; FIPV: Feline infectious peritonitis virus; MHV: Mouse hepatitis coronavirus; IBV: Infectious bronchitis virus; CT: Computerized Tomography; USFDA: United States Food and Drug Administration; EMA: European Medicines Agency; CEPI: Coalition for Epidemic Preparedness Innovations; CDC: Centers for Disease Control and Prevention; FIH: First-in-Human; FID: First Human Dose; NIAID: National Institute of Allergy and Infectious Disease.

\section{REFERENCES}

1. Stanley P. Another decade, another coronavirus. The New England Journal of Medicine. 2020;382:760-2.

2. Heilprin J. The associated press (AP). WHO Probe into deadly coronavirus delayed by sample dispute. Geneva CTV news. 2013.

3. Guangwen LU, Liu Di. SARS-like virus in the Middle East: A truly bat related coronavirus causing human diseases. Protein and Cell. 2012;3(11):803-5.

4. Acute respiratory illness associated with anew virus identified in the UK (report). Health Protection Agency. 2012. Archieved from the original on 1 February 2014.

5. https://www.aljazeerz.com/news/2020/01/china-coronavirus-500words200127065154334.html.

6. Coronavirus disease 2091(COVID-19), situation report -56. Data as reported by national authorities by 10AM CET6. 2020.

7. Gulfaraz K, Mohamud SH. The Middle East respiratory syndrome coronavirus: An emerging virus of global threat. Emerging and reemerging viral pathogens. Elsevier. 2020;8:151-67.

8. Susan WR, Julian LL. Coronavirus pathogenesis. Advances in virus research. Elsevier Inc: 2011;84:85-164

9. Middle respiratory syndrome coronavirus (MERS-CoV) - Saudi Arabia Disease Outbreak New: World Health Organization. 2015.

10. https://www.niaid.nih.gov/disease-conditions/coronaviruses

11. Woo PCY, Huang Y, Lau SK, et al. Coronavirus genomics and bioinformatics analysis. Viruses. 2010;2(8):1804-20.

12. Almeida JD, Berry DM, Cunningham $\mathrm{CH}$, et al. Virology: coronaviruses. Nature. 1968;220:650.

13. Sturman LS, Holmes KVM, Lauffer MA, Maramorosch K. The molecular biology of coronaviruses. Advances in Viral Research. 1983;28:35-112.

14. http://www.cdc.gov./coronavirus/types.html. 
15. Joel WO, Daniel CKW, et al. A case for the ancient origin of coronaviruses. Journal of Virology. 2013;87(12);7039-45.

16. Ziebuhr J, Thiel V, Gorbalenya AE. The autocatalytic release of a mutative RNA virus transcription factor from its poly protein precursor involves two paralogous papain-like proteases that cleave the same peptide bond. $\mathrm{J}$ of Boil Chem. 2001;276(35):33220-32.

17. Edgar RC. Muscle: Multiple sequence alignment with high accuracy and high throughput. Nucleic Acids Res. 2004;32(5):1792-7.

18. Chu DK, Peiris JS, Chen H, Guan Y, Poon LL. Genomic characterizations of bat coronaviruses (1A, 1B and HKU8) and evidence for co-infections in Miniopterus bats. J Gen Virology. 2008;89(5):1282-7.

19. Dewald S, Burtram FF. Coronavirus envelop protein: Current knowledge. Schoeman and Fielding Virology Journal. 2019;16(1):1-22.

20. Jimenez GJM, Nieto TJL, DeDiego ML, et al. The PDZ binding motif of severe acute respiratory syndrome coronavirus envelop protein is a determinant of pathogenesis. PLoS Pathog. 2014;10(8):e1004320.

21. Fang Li. Structure, functions and evolution of coronavirus spike protein. Annu Rev Virol. 2016;3(1):237-61.

22. Enjuanes L, Almazan F, Sola I, Zuniga S. Biochemical aspects of coronavirus replication and virus-host interaction. Annu Rev Micro. 2006;60:211-30.

23. Perlman S, Netland J. Coronaviruses post-SARS: update on replication and pathogenesis. Nat Rev Micro. 2009;7(6):4339-50.

24. Graham RL, Baric RS. Recombination, reservoirs and the modular spike: Mechanisms of coronavirus cross-species transmission. J Virol. 2010;84(7):3134-46

25. Li F. Receptor recognition and cross species infections of SARS coronavirus. Anti Virol Res. 2013;100(1):246-54.

26. Li WH, Wong SK, Li F, Kuhn JH, Huang IC, et al. Animal origins of the severe acute respiratory syndrome coronavirus insight from ACE2-S- protein interactions. J Virol. 2006;80(9):4211-9.

27. Kirchdoerfer RN, Cottrell CA, Wang N, Pallesen J, Yassine HM, et al. Pre-fusion structure of the human coronavirus spike protein. Nature. 2016;531(7592):118-21.

28. Walls AC, Tortorici MA, Bosch BJ, Frenz B, Rottier PJ, et al. Cryo-electron microscopy structure of a coronavirus spike glycoprotein trimer. Nature. 2016;531(7592):114-7.

29. Beniac DR, Undonov A, Grudeski E, Booth TF. Architecture of the SARS coronavirus perfusion spike. Nat Stru Mol Boil. 2006;13(8):751-52.

30. Li F, Berardi M, Li WH, Farzan M, Dogmatizer TR, Harrison SC Conformational states of the severe acute respiratory syndrome coronavirus spike protein ecdomain. J Virol. 2006;80(14):6794-800

31. Master PS. The molecular biology of coronaviruses. Adv Virus Res. 2006;66:193-292.

32. Mortola E, Roi P. Efficient assembly on release on SARS coronavirus like particles by a hererologus expression system. Febs Lett. 2004;576(1-2):174-8.

33. Wang $\mathrm{C}$, Zheng $\mathrm{X}$, Gai W, Zhao $\mathrm{Y}$, Wang $\mathrm{H}$, et al. MERS-CoV like particles produced in insect cells induces specific humoral and cellular immunity in Rhesus Macaques. Onco Target. 2017;8(8):12686-94.

34. http://en.wikipedia.org/wiki/file:coronavirus_virion_structure.svg

35. Muhammad A, Sherin SK, Abeer K, Nadia B, Rabaai S. COVID-19 infection: Origin, transmission and characteristics on human coronavirus. J of Adv Res. 2020;PII:S2090-1232(2030054/0)

36. Wang $\mathrm{N}$, Shi $\mathrm{X}$, Jaang L, Zhang $\mathrm{S}$, Wang $\mathrm{D}$, Tong $\mathrm{P}$, et al. Structure on MERS-CoV spike receptor-binding domain complexed with human receptor DPP 4. Cell Res. 2013;23(8):986.

37. Chan JFW, Kok KH, Zhu Z, Chu H, Tokk W, Yuan S, et al. Genomic characterization of 2019 novel human - pathogenic coronavirus isolated from a patient with a typical pneumonia after visiting Wuhan. Emerging Microbes and Infection. 2010;9(1):221-36.

38. Boheemen SV, Degrff M, Lauber C, Bstebroer TM, Raj VS, Zaki AM, et al. Genomic characterization of a newly discovered coronavirus associated with acute respiratory distress syndrome in humans. Mic Bio. 2012;3(6);e00473-12.

39. Raj BS, Mou H, Smith SL, Dekkers DH, Muller MA, Dijkmam R, et al. Di peptidyl peptidase 4 is a functional receptor for emerging human coronavirusEMC. Nature. 2013;495(7440)-251-4

40. Perlman S, Netland J. Coronavirus spores - SARS: Update on replication and pathogenesis. Nature Rev Micro. 2009;7(6):439-50.
41. Glowcka I, Bertram S, Muller MA, Allen P, Soilleux E, Pfefferle S, et al. Evidence that TMPR SS2 activates the severe acute respiratory syndrome coronavirus spike protein for membrane fusion and reduces viral control by humoral immune response. J of Virol. 2011;85(9):4122-34.

42. Bertram S, Govack I, Muller MA, Lavender H, Gnirss K, Nehalmeier I, et al. Cleavage and activation of the severe acute respiratory syndrome coronavirus spike protein by human airway trypsin like protease. J Virol. 2011;85(24):13363-72.

43. Wuhu F, Zhao S, Yub CYM, Wanh W, Song ZG, et al. A new coronavirus associated with human respiratory disease in China. Nature. 2020;125.

44. Zhou P, Yang X, Wang X, Hub B, Zhang L, Zhang W, et al. A pneumonia outbreak associated with a new coronavirus of probable bat origin. Nature. 2020;579(7798):270-3.

45. Xu X, Chen P, Wang J, Feng J, Zhou H, Li X, et al. Evolution of the novel coronavirus from the ongoing Wuhan Outbreak and modeling of its spike protein for risk of human transmission. Science China Life Sci. 2020;63(3):457-60.

46. Wan Y, Shang J, Graham R, Baric RS, Li F. Receptor recognition by novel coronavirus from Wuhan: an analysis based on decade-long structural studies of SARS. J of Virol. 2020:94(7).

47. Anthony FR, Stanley P. Coronavirus-an overview of their replication and pathogenesis. Methods Mole Bio. 2015;1282-23.

48. Krijan SC, Locker J, Ericsson M, Rutter PJM. Characterization of budding compartment of mouse hepatitis virus- evidence that transport from RER to Golgi complex requires only one vesicular transport step. J Cell Mol Bio. 1994;124(1):55-70.

49. Tooze J, Tooze S, Warren G. Replication of coronavirus MHV-A59 in sac cells-determination of the first sight of budding of progeny virions. Eur $\mathrm{J}$ Cell Biol. 1984;33(2):281-93.

50. Dehaan CA, Ruttir PJ. Molecular interactions in the assembly of coronaviruses. Adv Virus Res. 2005;64:165-230.

51. Raj VS, Mou H, Smits SL. Di peptidyl peptidase 4 is a functional receptor for the emerging human coronavirus-EMC. Nature. 2013;495(7440):251-4.

52. Yeager CL, Ashumun RL, William RK, et al. Human amino peptidase $\mathrm{N}$ is a receptor for human coronavirus 229 E. Nature. 1992;357(6377):420-2.

53. Hofmann H, Pyrc K, Vander HL. Human coronavirus NL63 employs severe acute respiratory syndrome coronavirus receptor for cellular entry. Procnatl Acd Sci USA. 2005;102(22):7988-93.

54. Delmas B, Gelfi J, Liharidon R. Amino peptidase $\mathrm{N}$ is the major receptor for the entero pathogenic coronavirus TGEV. Nature. 1992;357(6377):417-20.

55. Li BX, Ge JW, LI YJ. Porcine amino peptidase $\mathrm{N}$ is a functional receptor for the TEDV coronavirus. Virology. 2007;365(1):162-72.

56. Tresnan DB, Levis R, Hulmes KV. Feline amino peptidase $\mathrm{N}$ serves as a receptor for Feline, Porcine Canine and human coronavirus in sero group I. J Virol. 1996;70(12):8669-74.

57. Benbacer L, Kut E, Besnardeau L. Interspecies aminopeptidase N chimer's reveals species specific receptor recognition by canine coronavirus, Feline infectious peritonitis virus and transmissible gastroenteritis virus. J Virol. 1996;71(1):734-7.

58. Neddllcc P, Dveksler GS, Daniels E. BGP2, a new member of casino embryonic antigen-related gene family, encodes alternative receptors for mouse hepatitis virus. J Virol. 1994;68:4525-37.

59. Williams RK, Jiang GS, Holmes KV. Receptor for mouse hepatitis virus is a member of the carcino embryonic antigen family of glycoproteins. Procnatlacad Sci USA. 1992;88(13):5533-6.

60. Schultze B, Herrler G. Bovine coronavirus uses N-acetyl 9 O-acetyl neuraminic acid as a receptor determinant to initiate the infection of cultured cells. J Gen Virol. 1882;73(4):901-6.

61. Li W, Moore NJ, Vasilieva N. Angiotensin converting enzyme2 is a functional receptor for the SARS coronavirus. Nature. 2003;426(6965):450-4.

62. Mohamed E, EIZowalatya B, Josefjarhult D. From SARS to COVID-19 a previously unknown SARS-related Coronavirus (SARS - CoV2) of pandemic potential infecting humans: call for a one health approach. One Health 9. 2020;100124:1-6.

63. Zhou P, Fan H, Lan T, Yang XL, Shi WF, et al. Fatal swine acute diarrhoea syndrome caused by an HKU2-related coronavirus of bat origin. Nature. 2018; 556(7700):255-8. 
64. Kelly TR, Karesh WB, Johnson CK, Gilardi KV, Anthony SJ, et al. One Health proof of concept: Bringing a Trans disciplinary approach to surveillance for Zoonotic viruses at the human-wild animal interface. Preventive Vet Med. 2017;137:112-8.

65. Lebov GK, Womack D, Zaccaro D, White HN, et al. A frame work for One Health research. One Health. 2017;3:44-50.

66. Wuhan sea food market may not be only source of novel coronavirus: Expert. 2020. http://www.xinhuanet.com/English/2020-01/29/c_138741063.htm.

67. Lu L, Milinovich GJ, Hu W. A Brief historical over view of emerging infectious disease response in China and the need for a One Health approach in future responses. One Health. 2016;2:99.

68. Bande F, Arshad SS, Bejo MH, Moeini H, Omer AR. Progress and challenges towards the development of vaccines against avian infectious bronchitis. J of Immu Res. 2015;12. Doi-101155/2015/424860.

69. Kamps G, Todt D, Pfander S, Steinmann E. Persistence of coronavirus on inanimate surfaces and their inactivation with biocidal agents. J of Hos Inf. 2020;104(3):246-51.

70. Vandoremalen N, Bushmaker T, Muster VJ. Stability of Middle East respiratory syndrome coronavirus (MERS to $\mathrm{CoV}$ ) under different environmental conditions. Euro Survell. 2013;18(38):20590.

71. Casanova LN, Jeon S, Rutula WA, Weber VJ, Sobsey ND. FX of air temperature and relative humidity on coronavirus survival on surfaces. Appli and Virion Micro. 2010;76(9):271-7.

72. Warnes SL, Little ZR, Keevil CW. Human coronavirus $229 \mathrm{E}$ remains infectious on common touch surface materials. M Bio. 2015;6(6):e01697e15.

73. Sizun J, Yu MW, Talbot PJ. Survival of human coronavirus $229 \mathrm{E}$ and OC43 in suspension and after drying on surfaces: A possible source of hospital acquired infections. J Hos Infect. 2000;46(1):55-60.

74. Sanduan SM, Zhao XS, Wen RF, Huang JJ, Pi GH, Zhang SX, et al. Stability of SARS coronavirus in human specimens and environment and its sensitivity to heating and UV irradiation. Biomed Env Sci. 2003;16:246e55.

75. Lai MY, Cheng PK, Lim WW. Survival of severe acute respiratory syndrome coronavirus. Clin Infect Dis. 2005;41(7):e67-71.

76. Chan KH, Peiris JS, Lam SY, Poon LL, Yuen KY, Seto WH. The effects of temperature and relative humidity on the viability of SARS coronavirus. Adv Virol. 2011;734690.

77. Rabenau HF, Cinatl J, Morgensgenrn B, Bauer G, Preiser W, Doerr SW. Stability and inactivation of SARS coronavirus. Med Micro Immun. 2005;194(1-2):1-6.

78. http://www.who.int/emergencies/disseases/novel-coronavirus-2019/advicefor-public.

79. Hussinrothana A, Siddappa BRA. The epidemiology and pathogenesis of coronavirus disease (COVID-19) outbreak. J of Autolmmunity. 2020;102433.

80. Ren LL, Wang YM, Wu ZQ, Xiang JC, Gou L, Xu T. Identification of novel coronavirus causing severe pneumonia in human: A descriptive study. Chinese Med J. 2020. http://doi.org/10.1097/CM9.0000000000000722.

81. Huang C, Wangli $X$, Ren L, Zhao J, Hu Y. Clinical features of patients infected with 2019 novel coronavirus in Wuhan, China. Lancet. 2020;395(10223):497-506.

82. Nishiura H, Juan SM, Linton NM, Kinoshita R, Yang Y, Hayashi K. The extent of transmission of novel coronavirus in Wuhan, China. J Clin Med. 2020;9.

83. Li Q, Guan X, Wu P, Wang X, Zhou L, et al. Early transmission dynamics in Wuhan, China of novel coronavirus-infected pneumonia. N. Engl J Med. 2020;2001316.

84. Lu H. Drug treatment options for the 2019- new coronavirus (2019-nCoV). Bio Sci Trend. 2020;14(1):69-71.

85. Carlos WG, Delacruz DS, Cao B, Pasnick S, Jamil S. Novel Wuhan (2019 nCoV) coronavirus. AM J Respire Crit Care Med. 2020;201(4):7-8.

86. Lei L, Li J, Li X, Qi X. CT imaging of 2019 novel coronavirus (2019 nCoV) pneumonia. Radi. 2020;200236.

87. Phan LT. Nunguen TV, Luong QC, Nguen HT, Le HQ. Impartation and human to human transmission of novel coronavirus in Vietnam. N Engl J Med. 2020.

88. http://en.m.wikipedia.org.home.

89. http://www.who.int/news-room/detail/07-04-2020-who-lists-two-covid-19tests-for-emergency-use.

90. Kupferschmidt K, Cohen J. WHO launches global mega trial of four most promising coronavirus treatments science magazine. 2020. doi:101126/ science. abb8497.
91. First regulatory workshop on COVID-19 facilitates global collaboration on vaccine development. European Medicines Agency. 2020.

92. Coronavirus COVID-19 update; FDA continues to facilitate the development of treatments. USFDA. 2020.

93. China approves first anti-viral drug against coronavirus COVID-19. Clinical Trials Arena. 2020.

94. Chinese vaccine approved for human testing at virus epicenter. Bloomberg News. 2020.

95. Dhama K, Sharul K, Tiwari R, Dadar M, Malik YS, Singh KP. COVID-19 an emerging corona virus infection: Advances and prospects in developing and designing vaccines, Immuno therapeutics. Human Vaccines and Immuno Therapeutics. 2020:1-7.

96. Zhang L, Liu Y. Potential inventions for novel coronavirus in China: A systematic review. J Med Virol. 2020;92(5):479-90.

97. Fox, Maggie. Drug makers are racing to develop immune therapies for COVID-19. Will they be ready in time?. 2020.

98. Chan M. Chinese military scientist order to win global race to develop coronavirus vaccine. South China Morning Post. 2020.

99. Cheng ML, Todd LC, Tan DH, Murthy S. Generating randomized trial evidence to optimize treatment in the COVID-19 pandemic. Canadian Med Assoc J. 2020;192(15):E405-7.

100. http://www.cdc.gov/media/releases/2020/s0404-covid19-survelliance-reporthtml.

101. COVID-19 treatment a vaccine tracker. Milken Institute. 2020. Lay summary.

102. Draft Landscape of COVID-19 candidate vaccine. World Health Organization. 2020. Retrieved 21 March 2020.

103. Cillaian OB. Vaccine watch colons there are efforts being made around the world. CTV News. 2020.

104. The drug development process. USFDA. 4 January 2018. 2020.

105. Strove J, Sittampalam S, Coussens NP, Hughes M, et al. Early drug discovery and development guidelines: For academic researchers' collaborator and startup companies. Assay Guidance manual Elli Lilly and company and the national center for advancing translational sciences. 2016. PMID22553881.

106. Taylor D. The pharmaceutical industry and future of drug developments issues in environmental science and technology. Royal Society of Chemistry. 2015/1-33.

107. NIH clinical trial of investigational vaccine for COVID-19 begins. US National institutes for health. 2020. Retrieved 17 March 2020.

108. Mak E. China approves first home ground COVID-19 vaccine to enter clinical trials. Bio World. 2020. Retrieved 24 March 2020.

109. Selina K, Wnniepong. First up for COVID-19: nearly 30 clinical read outs before end of April. Bio Century Inc. 2020. Retrieved .1 April 2020.

110. COVID-19 clinical research collations. Global collations to accelerate COVID-19 clinical research in resource-limited settings. Lancet. 2020. Doi:10.1016/s0140-6736 (20)30798-4.

111. https://www.who.int/publications/m/item/draft-landscape-of-covid-19candidate-vaccine.

112. Carey K. Increasing number of biopharma drug target COVID-19 as virus spreads. Bio World. 2020. Retrieved 1 March2020.

113. Government of Canada funds 49 additional COVID-19 research projectsdetails of funded projects. Government of Canada. 2020. Retrieved 23 March 2020.

114. Gregory A. Coronavirus -Japanese anti-viral drug effective in treating patients, Chinese officials says. The independent. 2020. Retrieved 19 March 2020.

115. Hannah S. FDA approves phase III clinical trial of Tocilizumab for COVID-19 Pneumonia. Cancer network, MJH Life Sci. 2020. Retrieved 28 March 2020.

116. Denisehinton M. Request for emergency use authorization for use of Chloroquine phosphate or Hydroxy chloroquine sulphate supplied form the strategic national stuff pile for treatment of 2019 coronavirus disease. USFDA. 2020. Retrieved 30 March 2020.

117. https://m.times of india.com/life-style/health-fitness/health-news/indiascoronavirus-vaccine-vaccine-status-test-results-and-all-you-need-to-know/ amp_etphotostory /77192458.cms.

118. https://science.thewire.in/health/how-indigenous-is-bharath-biotechs-newcovid-19-vaccine-covaxin/. 
PICTORIAL ABSTRACT

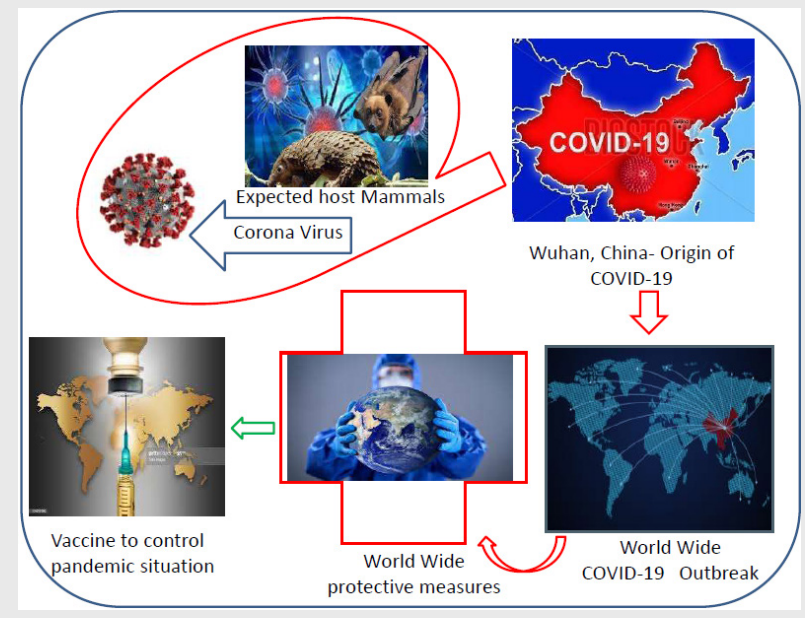

\section{SUMMARY}

- The coronavirus pandemic has become a never ending destination as it is being infectious all over the world.

- To sum up the study we have discussed about the origin of the virus, structure of the virus and habitats has been discussed.

- The mechanism and type of the virus binding with type of receptor on the host cell and lifecycle of the virus is explained.

- The persistence of coronavirus on inanimate surfaces and its life span depending on the time, temperature is being discussed.

- The symptoms of the infected person and precautionary measures has been specified in the study which are the guidelines implemented by different key organizations in collaboration with other institutions and explained a glance report about the drugs and vaccine development.

\section{About Author}

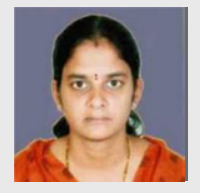

Dr. Gajula Chinna Devi University College of Pharmaceutical Sciences Palamuru University Mahabub Nagar-509001, Telangana State, India.

Cite this article: Devi GC. World Wide Uncharted Trajectory Outbreak Initiator: Coronavirus [COVID-19] Pathogenesis. Indian J of Pharmaceutical Education and Research. 2021;55(1):11-20. 